\title{
Kaposi's sarcoma of the tonsils
}

\author{
Brendan Wright
}

ENT, Health and Social Care Services in Northern Ireland, Belfast, UK

\section{Correspondence to Brendan Wright} bwright01@qub.ac.uk

Accepted 27 July 2017
CrossMark

To cite: Wright B. BMJ Case Rep Published Online First: [please include Day Month Year]. doi:10.1136/bcr-2017219714

\section{DESCRIPTION}

A 19-year-old HIV-positive man was referred to the ENT (ear, nose and throat) team with dysphagia and intermittent hearing loss. He had a CD4 count of 70 cells $/ \mathrm{mm}^{3}(9 \%)$ and was receiving antiretroviral treatment (Raltegravir and Truvada). He had known Kaposi's sarcoma (KS) skin lesions on the neck and arms, and a left-sided level 5 neck node biopsy was positive for KS.

He gave a 2-week history of dysphagia at the level of the hyoid bone, as well as intermittent episodes of haemoptysis and haematemesis. He also described bilateral intermittent hearing loss over 2 weeks.

On examination there were large, irregular lesions on both tonsils, which clinically appeared to be KS (figure 1). There were several firm lymph nodes in the posterior triangle of the neck bilaterally and in the left supraclavicular fossa. Both tympanic membranes were dull and retracted. Flexible nasoendoscopy revealed a large adenoid pad with the appearance of a Kaposi's lesion (figure 2) and the hypopharynx and larynx were clear. An audiogram showed a bilateral conductive hearing loss and tympanograms were flat, in keeping with bilateral glue ear.

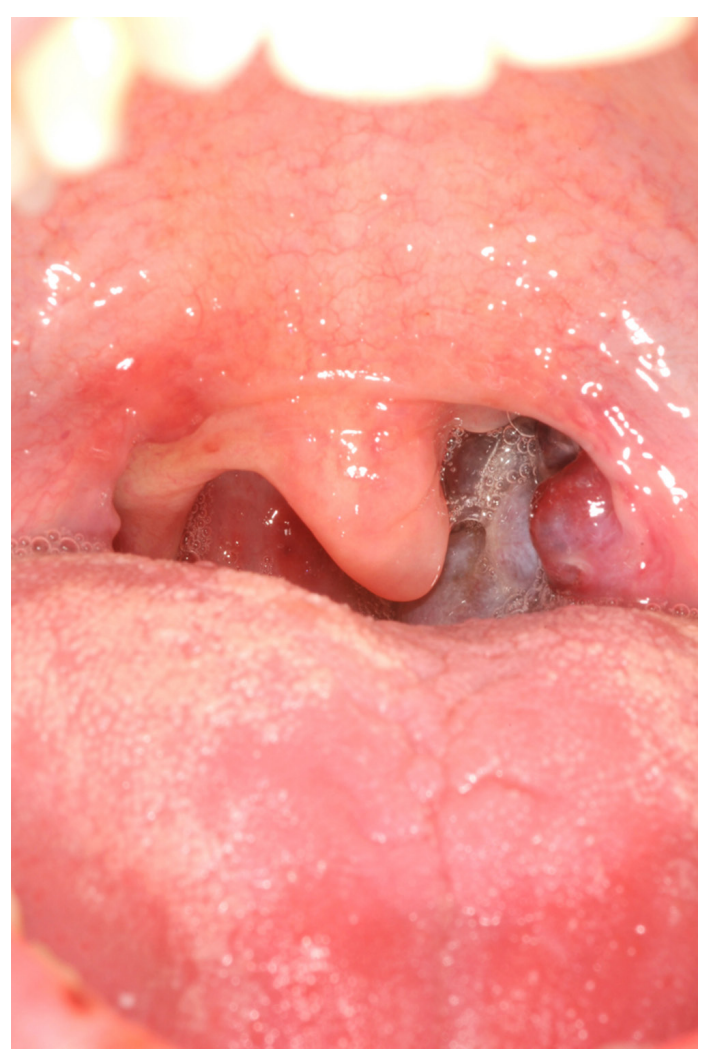

Figure 1 A Kaposi's lesion is visible on the left tonsil (the right tonsillar lesion is just out of view).

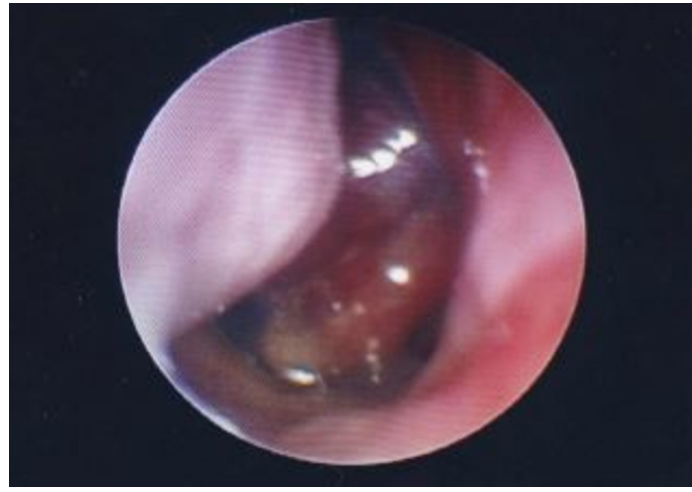

Figure 2 A large adenoid swelling with the appearance of a Kaposi's lesion is visible in the postnasal space viewed through the right nasal cavity (inferior turbinate on the left hand side and nasal septum on the right hand side).

A histological diagnosis was not made on the adenoid and tonsils given the clear clinical diagnosis and because it would not change the patient's management. The patient was proceeding to have liposomal doxorubicin treatment.

KS is rarely reported to affect the tonsils, ${ }^{12}$ with one case series finding a prevalence of $8.3 \%$ for tonsillar KS in patients with KS of the head and neck region. ${ }^{3}$

\section{Learning points}

- Kaposi's sarcoma can affect the tonsils in HIV-positive patients.

- Consider Kaposi's lesions in the oropharynx as a possible cause of dysphagia in an HIV-positive patient.

Contributors Article devised and written by the corresponding author.

Competing interests None declared.

Patient consent Obtained.

Provenance and peer review Not commissioned; externally peer reviewed.

(C) BMJ Publishing Group Ltd (unless otherwise stated in the text of the article) 2017. All rights reserved. No commercial use is permitted unless otherwise expressly granted.

\section{REFERENCES}

1 Raikundalia KB. Kaposi's sarcoma of tonsil. J Laryngol Otol 1973;87:295-7.

2 Pittore B, Pelagatti CL, Deiana F, et al. Isolated kaposi sarcoma of the tonsil: a case report and review of the scientific literature. Case Rep Otolaryngol 2015;2015:1-5.

3 Yu DX, Pi SJ, Zhang WS. Clinical manifestation of Kaposi sarcoma in otorhinolaryngology head and neck surgery. Zhonghua Er Bi Yan Hou Tou Jing Wai Ke Za Zhi 2013;48:241-3. 
Copyright 2017 BMJ Publishing Group. All rights reserved. For permission to reuse any of this content visit http://group.bmj.com/group/rights-licensing/permissions.

BMJ Case Report Fellows may re-use this article for personal use and teaching without any further permission.

Become a Fellow of BMJ Case Reports today and you can:

- Submit as many cases as you like

- Enjoy fast sympathetic peer review and rapid publication of accepted articles

Access all the published articles

- Re-use any of the published material for personal use and teaching without further permission

For information on Institutional Fellowships contact consortiasales@bmjgroup.com

Visit casereports.bmj.com for more articles like this and to become a Fellow 